\title{
The Effects of Corporate Governance, Corporate Social Responsibility, and Intellectual Capital Disclosure on the Sustainability of Banking Sector in Bangladesh
}

\author{
Dr. Nisar Ahmed \\ Professor, Department of Finance, American International University-Bangladesh \\ 408/1, Kuratoli, Khilkhet, Dhaka 1229, Bangladesh \\ E-mail: nisarsn@aiub.edu
}

Md. Joynal Abedin (Corresponding author)

Asst. Professor, Department of Finance, American International University-Bangladesh 408/1, Kuratoli, Khilkhet, Dhaka 1229, Bangladesh

E-mail: abedin@aiub.edu

Received: September 12, 2019 Accepted: October 11, 2019 Published: October 15, 2019

doi:10.5296/ber.v9i4.15427ＵRL: https://doi.org/10.5296/ber.v9i4.15427

\begin{abstract}
Sustainability is one of the most cornering issues for the current corporate world. Wide realization has been adapted by the major organizations where everybody endorses to do business in a long run, not just to maximizing the profit. Aiming to create better environment for the future generations, several steps has been taken by various local and international associations and bodies. The focus areas that ensure sustainable practice are intellectual capital disclosure, CSR expenditure, infrastructural asset, research and development expenses, corporate governance structure, green banking policy, financial development, environmental effects and many other factors. Firms are aware of maintaining these factors effectively to sustain in the market. Sustainability is a massive subject and various component are related with this major issue. Recently three of the components such as Corporate Governance, Corporate Social Responsibility and Intellectual Capital Disclosure has grabbed the major attention and maintained with an important manner. Private commercial banking sector is one of the most popular and growing sectors in Bangladesh. Due to high competition, to sustain in the market is difficult for those banks. As a turn out various components of sustainability
\end{abstract}


are effectively maintained by the banks. This paper shows how CG, CSR and ICD affect the sustainable practice of the private commercial banking sector in Bangladesh. It also relates various components and shows ways to improve the sustainable practice in our current situation.

Keywords: Corporate Governance, Banking Sector, Sustainability, Bangladesh, Corporate Social Responsibility, Intellectual Capital Disclosure

\section{Introduction}

To sustain in the market and be more efficient, corporate world is changing at a rapid pace. As a result, all kind of traditional tools, techniques and procedures has been continuously replaced by the conventional methods and approaches. Some of the most talked about and spotted concepts that shape the modern financial world are Corporate Governance, Intellectual Capital and Corporate Social Responsibility. These concepts are adopted worldwide and considered as the ultimate solution of sustainability.

Alike the rest of the world, organizations in Bangladesh is also adopted so many modern approaches and tactics to compete and to be more efficient. Especially the banking sector of Bangladesh is vast and still emerging. There are a total of 59 Banks including 41 Private Commercial Banks. In terms of the size of its economy the banking sector of Bangladesh is somewhat larger than many economies of allied level of growth and associated indices which results high competition. To maintain a healthy competition, strict procedures and initiatives has been taken by the Central Bank of Bangladesh. On the other hand, management from these banking financial institutions is also eager and striving to survive in the market. Besides the BASEL framework which is mandatory for all the banks, Corporate Governance, Intellectual Capital and Corporate Social Responsibility considered the paramount element for advancement to the present financial success. This paper tends to provide the information regarding the Corporate Governance, Intellectual Capital and Corporate Social Responsibility implementation condition of the banks, current situation after implementation and long-term prospects and drawbacks of adopting those practices. Simply this report aims to evaluate the results of Corporate Governance, Intellectual Capital and Corporate Social Responsibility carrying out in conventional private commercial banks of Bangladesh. As the selected topics have been considered as the major responsibilities in the developed countries and conduct with due interest and effort. A high possibility of new trend is forthcoming regarding the selected topic in the current Bangladesh market. As a result; the future employees must have a good knowledge about the Corporate Governance, Intellectual Capital and Corporate Social Responsibility practices and its consequences.

Our world is shifting towards knowledge economy from the manufacturing era. It affects the business sector that has progressed over the previous years from traditional 'profit maximizing' loom to a 'socially responsible' face where organizations are not only accountable to its shareholders but also to all its participants in a comprehensive intelligence. As a result, techniques and methods are preferable then the mechanism now a days. Some of the most important tools that shape the modern corporation and financial institutions are Corporate Governance, Intellectual Capital Disclosure and Corporate Social Responsibility. 
These ultimate approaches cost firms some cash outlays which have consequences on their financial performance. Organization's accountability in building an improved prospect is distinguished and gives confidence by internal and external environment of the firm; which may eventually accompany the businesses towards the sustainability.

Corporate Governance, in the simplest terms is a purposefully built structure of policies, norms and rules which govern corporations to make it fully functional in terms of its responsibilities to all its stakeholders. In 2009, the world watched in horror of the tumbling down of numbers on international financial markets. On that time, center of all discussion was 'Corporate Governance'. It is the one force that keeps all the pillars of a corporation and in turn, collectively that of the economy, in their places.

Since corporations do not exist in segregation but exist inside a society, therefore businesses need to add optimistically to the advancement of society in which they are operated. Corporate Social responsibility inventiveness has become an essential part of business process, despite of the market's isolation. CSR practices have been increasingly becoming an essential part of global business practices in addition to one of the vital issues for market right of entry; it is becoming uniformly influential for local satisfactoriness. It is one of the acts for compassion to endow with good operational atmosphere for an organization's member of staffs, to forfeit remuneration, to provide usual leave, to heed as human beings and to think about environment.

The topical mega corporate fall in some developed countries has heightened the need to assess stipulation of related intangible information to potential investors. The intellectual capital (IC) corresponds to a split of such assets not distinguished in financial positions. Intellectual Capital is intellectual resource that has been recognized, confined and leveraged to create a higher-priced asset and if effectively managed leading to potential advantage that does not have a physical or financial incarnation.

\section{Literature Review}

Simply; Sustainability means doing business without creating any adverse effect on future generations. It can be defined as meeting our own needs without compromising the ability of future generations to meet their own needs. In addition to natural resources, we also need social and economic resources. Sustainability is not just environmentalism. Embedded in most definitions of sustainability we also find concerns for social equity and economic development (Brundtland Commission, 1987). Sustainable Finance is defined as the provision of financial capital and risk management products to projects and business that promote or do not harm economic prosperity, environmental protection and social justice (Forum for the Future, 2002). We can say that sustainably is based on three pillars; Environment, Economy and Social. However different research may oppose about the pillars and support few more components.

Sustainability is a process that helps to create a vibrant economy and a high quality of life, while respecting the need to sustain natural resources and protect the environment. It expresses the principle that future generations should live in a world that the present 
generation has enjoyed but not diminished (Clough, 2006). Sustainability is a vision for the world in which current and future humans are reasonably healthy; communities and nations are secure, peaceful and thriving; there is economic opportunity for all; and the integrity of the life-supporting biosphere is restored and sustained at a level necessary to make these goals possible. All four dimensions of sustainability must be addressed to achieve this vision (Cortese \& Rowe, 2002).

The financial sector is a critical channel through which price signals, regulation, and civil society pressure can direct financial capital to sustainable economic activity (Pearce, 2002). Sustainable Banking can be defined as a decision by banks to provide products and services only to customers who take into consideration of the environmental and social impacts of their activities (Bouma et al, 2001). Banks are the backbone of the global economy, providing capital for innovation, infrastructure, job creation and overall prosperity. Banks also play an integral role in society, affecting not only spending by individual consumers, but also the growth of entire industries (Douglas, 2008). Banks are moving from defensive banking, where management of social and environmental impacts is seen as an additional cost, to sustainable banking, where sustainable development is seen as an advantage and an opportunity for growth (International Finance Corporation, 2007). Bank sustainability does not necessarily imply higher costs, more bureaucratic processes and lower financial returns. Sustainability is firmly rooted in a business perspective where socio environmental performance goes hand in hand with economic performance, a change of paradigm that prioritizes permanence and perpetuation of the organization (Rahman \& Kamruzzaman, 2014). Two principles are extremely important in promoting corporate sustainability: corporate governance and innovation (Rahman \& Kamruzzaman, 2014).

Corporate governance deals with the ways in which suppliers of finance to corporations assure themselves of getting a return on their investment (Shleifer \& Vishny, 1997). One can expand on this definition and define corporate governance to be concerned with the resolution of collective action problems among dispersed investors and the reconciliation of conflicts of interest between various corporate claimholders. This would broaden the conflicts to not only those between management and investors but also to those among investors.

One of the important aspects of good corporate governance is the full disclosure of all relevant information about the firm and its activities including full disclosure of ownership structure, accounting and financial statement kept under International Financial Reporting Standards (IFRS), good internal controls in place, with an external independent auditor and a well-defined risk management policy in place.

Intellectual capital is defined as intangible assets which include technology, customer information, brand name, reputation and corporate culture that are invaluable to a firm's competitive power (Low \& Kalafut, 2002). Intellectual capital consists of three components. The first component is tacit knowledge and innovativeness of the employees. The second component is infrastructure of human capital such as good working system, innovation and improvement processes of structural capital and the last components is external relationships of the firm such as customers' capital. 


\section{Macrothink}

Business and Economic Research

ISSN 2162-4860

2019, Vol. 9, No. 4

The value of intangible assets within organizations, such as human and intellectual capital, has increased significantly in recent years as the global economy has become more knowledge intensive. But Intellectual capital and intangible assets in general pose real challenges for governments, regulators and firms (O'Regan et al, 2001). A key challenge is the need to identify theoretical and practical solutions to the recognition, measurement and reporting of intangible assets, processes and potentials not heretofore tracked by traditional accounting metrics (Abeysekera, 2006). Information on a firm's human resources, innovation, customers, or technology cannot be included in financial statements because of identification, recognition, and measurement problems (Hidalgo et al, 2011).

\section{Hypothesis Development}

The research focuses on the sustainability opportunity and issues model, its components and the inter connection among them. It develops a structural model to prove these connections based on the premise that good board practice is responsible for developing higher expenditure on CSR. Further, it also tends to prove that fair Disclosure on Intellectual capital can affect the Corporate Governance structure in a way it will increase the overall CG performance.

Table 1. Hypothesis Development

\begin{tabular}{|l|l|l|}
\hline Hypothesis No. & Hypothesis & Suggested Effect \\
\hline H1 & $\begin{array}{l}\text { All else being constant, companies with good board practices tend } \\
\text { to have higher expenditure in Corporate Social Responsibility (CSR). }\end{array}$ & + \\
\hline H2 & $\begin{array}{l}\text { All else being constant, companies with high Intellectual Capital } \\
\text { Disclosures tend to have good Corporate Governance (CG) Practices. }\end{array}$ & + \\
\hline
\end{tabular}

\section{Structural Framework}

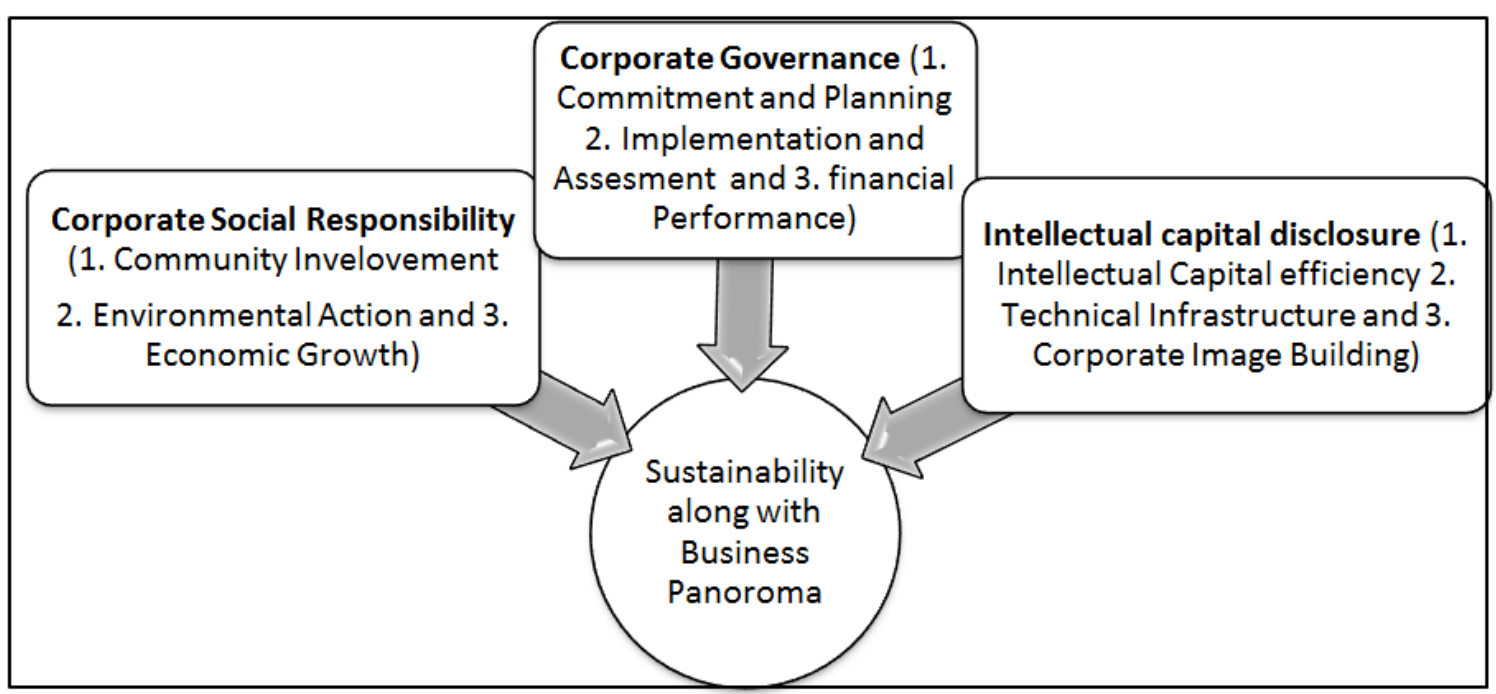

Figure 1. Structural Framework 


\section{Research Methodology}

\subsection{Source of Data}

This study has been a pursuit to determine the sustainability of commercial banking sector and relate the influence of CG, CSR and IC Disclosure. This study approach is research based. There is only involvement of secondary data. The information is collected from Annual Reports of 30 Banking Financial Institutions. Data also collected by reference books, magazines, journals and visiting the organization and based on this information analysis has been conducted. This is also a scoring-based research or survey. This variable are also the elements that Security exchange Commission (SEC) of Bangladesh make it mandatory for all the Banking Financial Institutions to show in their annual reports. However, with this data's, various statistical methods such as mean, standard deviation and correlation matrix has been calculated. In addition, this survey also shows the percentage of disclose information, minimum and maximum number of various variables.

\subsection{Report Design}

This study attempts to measure sustainability of commercial banking sector focus on CG, ICD and CSR based on stratified sampling methods. Selected 30 private commercial banks are listed in Dhaka Stock Exchange (DSE). The research is quantitative and based on three years data gathered from audited annual reports of the banks covering the period 2011-2015. The DSE companies have been selected for research; keeping in view that most of the listed companies are big enough to develop and exploit CG, CSR and IC assets. Comprehensive data on CG, IC and CSR can be extracted from audited annual reports of these publicly traded companies easily. Moreover, the stratified sample of DSE listed companies cover 30 banks, thus increasing the accuracy of the research outcome.

Based on this information, this paper aims to examine various prospects using of independent and dependent variables related to this topic. However, this data will be used to calculated mean, standard deviation and correlation of all the banks. The data will be cross section as well as time series. Data has been analyzed and filtered through SPSS Software. The study put more emphasis on the survey results, findings and recommendations part. It is prepared using computer to type the entire report and by browsing the internet to gather secondary information. Wide ranges of books, journals etc. are available on this topic which help acquire ideas from there, but own creativity and imagination will be given the maximum priority to prepare this report.

Table 2. Independent \& Dependent Variables

\begin{tabular}{|c|c|c|c|}
\hline \multicolumn{4}{|l|}{ Corporate Governance (Scoring System) } \\
\hline & Criteria set by SEC & Comply & Do not Comply \\
\hline 1. \% of independent directors on board & At least $1 / 5^{\text {th }}$ & 1 & 0 \\
\hline $\begin{array}{l}\text { 2. Is CEO and the chairperson of the board } \\
\text { being different person? }\end{array}$ & $\begin{array}{l}\text { Should be different } \\
\text { individuals }\end{array}$ & 1 & 0 \\
\hline 3. Number of audit committee members & At least 3members. & 1 & 0 \\
\hline 4. Number of board meeting per year & Should be 20 and more & 1 & 0 \\
\hline
\end{tabular}




\begin{tabular}{|c|c|c|c|}
\hline $\begin{array}{l}\text { 5. Gender diversity on the board } \\
\text { (male-female ratio) }\end{array}$ & Should be a diversify board & 1 & 0 \\
\hline 6. Board size: number of board members & $\begin{array}{l}\text { Board members should not } \\
\text { be less than } 5 \text { and more than } \\
20\end{array}$ & 1 & 0 \\
\hline $\begin{array}{l}\text { 7. Compliance with International Accounting } \\
\text { Standards }\end{array}$ & $\begin{array}{l}\text { Compliance with IASB \& } \\
\text { IAS }\end{array}$ & 1 & 0 \\
\hline 8. Independent director & $\begin{array}{l}\text { At least } 1 / 10 \text { th i.e. minimum } \\
\text { one }\end{array}$ & 1 & 0 \\
\hline \multicolumn{4}{|l|}{ Corporate Social Responsibility } \\
\hline \multicolumn{4}{|l|}{ 9. CSR expenditure } \\
\hline \multicolumn{4}{|l|}{ Intellectual Capital } \\
\hline \multicolumn{4}{|l|}{ 10. MVA } \\
\hline \multicolumn{4}{|l|}{ Sustainability } \\
\hline \multicolumn{4}{|l|}{ 11. Profit After Tax } \\
\hline \multicolumn{4}{|l|}{ 12. Total assets } \\
\hline \multicolumn{4}{|l|}{ 13. ROA } \\
\hline \multicolumn{4}{|l|}{ 14. $\mathrm{ROE}$} \\
\hline \multicolumn{4}{|l|}{ 15. \% of domestic shareholding } \\
\hline \multicolumn{4}{|l|}{ 16. No of employees } \\
\hline \multicolumn{4}{|l|}{ 17. Training \& development expenditure } \\
\hline \multicolumn{4}{|l|}{ 18. Total infrastructural asset } \\
\hline Sustainability (Scoring System) & & Comply & Do not Comply \\
\hline 19. Implementation of ERP & $\begin{array}{l}\text { Already implemented } \\
\text { Enterprise Resource Planning } \\
\text { (ERP) }\end{array}$ & 1 & 0 \\
\hline 20. Certifications & $\begin{array}{l}\text { Certify by National \& } \\
\text { international awarding bodies }\end{array}$ & 1 & 0 \\
\hline 21. Adopted green banking policy & $\begin{array}{l}\text { Already adopted green } \\
\text { banking policy guided by } \\
\text { Bangladesh Bank }\end{array}$ & 1 & 0 \\
\hline $\begin{array}{l}\text { 22. Providing long-term incentives \& } \\
\text { sanctions }\end{array}$ & $\begin{array}{l}\text { Providing low interest loans } \\
\text { and other long-term benefits }\end{array}$ & 1 & 0 \\
\hline
\end{tabular}

\section{Analysis and Interpretation of the Data}

Total 30 private commercial Banks have been taken to conduct the analysis among them most of the banks operated in Bangladesh for more than 5 years. To get the accurate result some new banks also included in the analysis even though it is widely believing that new banks are very much fluctuate in various dates. To conduct first part of the analysis, total 22 variables has been used to determine the sustainability, CSR, CG and ICD results of those banks. After getting one by one four sector results, correlation among these four subjects has been 


\section{Macrothink Institute ${ }^{\text {TM }}$}

determined to check the relation among sustainability, CSR, CG and ICD. All the required data's have been taken using the annual reports. Some of the variable's values are possible to get directly from the annual reports. Table 3 shows the 10 of such variables. In the other hands, other variables are not possible to get directly from available sources. Thus, scoring basis has been used to measure these variables. Table 3 also shows the 12 variables with the basis of scoring and explanations. In addition, the various statistical formulas have been used in order to determine the components. All the calculations and ranking are based on this table.

Table 3. Sustainability indicators (Numerical Values)

\begin{tabular}{|c|c|c|c|c|c|c|c|c|c|c|c|c|c|c|c|}
\hline & \multicolumn{5}{|c|}{ Mean } & \multicolumn{5}{|c|}{ Standard deviation } & \multicolumn{5}{|c|}{ Total } \\
\hline & 2015 & 2014 & 2013 & 2012 & 2011 & 2015 & 2014 & 2013 & 2012 & 2011 & 2015 & 2014 & 2013 & 2012 & 2011 \\
\hline PAT & 74353 & 65754 & 45201 & 24125 & 18646 & 3950 & 3080 & 1545 & 808 & 698 & 74353 & 65754 & 45201 & 24125 & 18646 \\
\hline TA & 165227 & 146050 & 176752 & 115802 & 102141 & 977086 & 858370 & 205388 & 182847 & 114810 & 5396018 & 3943370 & 4772309 & 3242464 & 2852204 \\
\hline ROA & 0.99 & 0.97 & 0.84 & 0.62 & 0.59 & 0.64 & 0.58 & 0.44 & 0.54 & 0.42 & - & - & - & - & - \\
\hline ROE & 14.55 & 11.36 & 10.30 & 7.45 & 4.21 & 3.27 & 4.65 & 5.04 & 6.14 & 6.82 & - & - & - & - & - \\
\hline PDS & 96.22 & 95.44 & 95.44 & 67.98 & 67.98 & 10.41 & 11.53 & 11.53 & 43.44 & 43.44 & 2907 & 2767 & 2767 & 1971 & 1971 \\
\hline NOE & 2966 & 2096 & 1860 & 1791 & 1432 & 2688 & 1990 & 1759 & 1861 & 1698 & 83693 & 60805 & 53962 & 51957 & 42058 \\
\hline T\&D & 17.3 & 11.67 & 8.44 & 5.83 & 2.54 & 18.61 & 12.09 & 8.97 & 7.44 & 4.96 & 749.36 & 338.56 & 244.66 & 169.06 & 109.3 \\
\hline IA & 5585 & 4927 & 5071 & 2095 & 1965 & 13025 & 10062 & 12640 & 6033 & 2983 & 18297501 & 14289467 & 14707140 & 6078158 & 5147856 \\
\hline
\end{tabular}

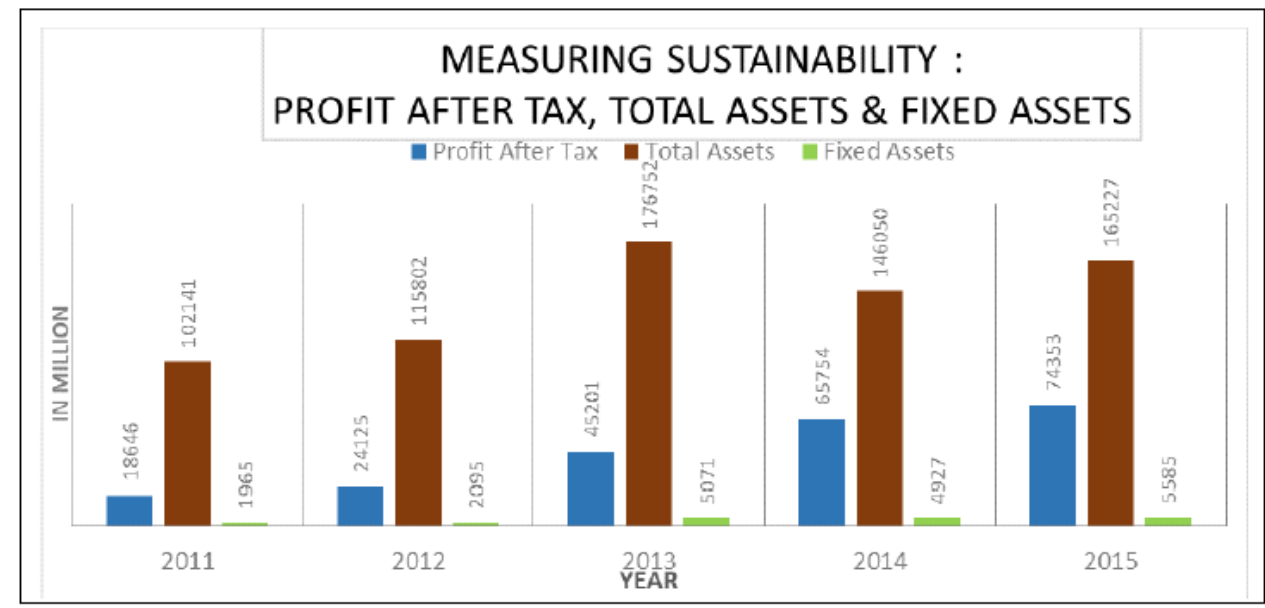

Figure 2. Measuring Sustainability through Profit after Tax, Total Assets and fixed Assets

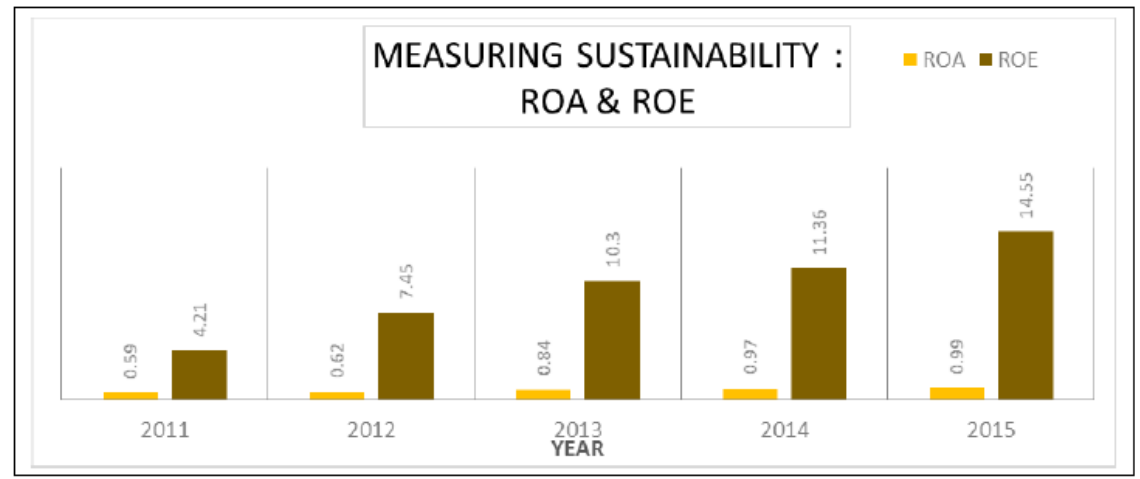

Figure 3. Measuring Sustainability through ROA and ROE 


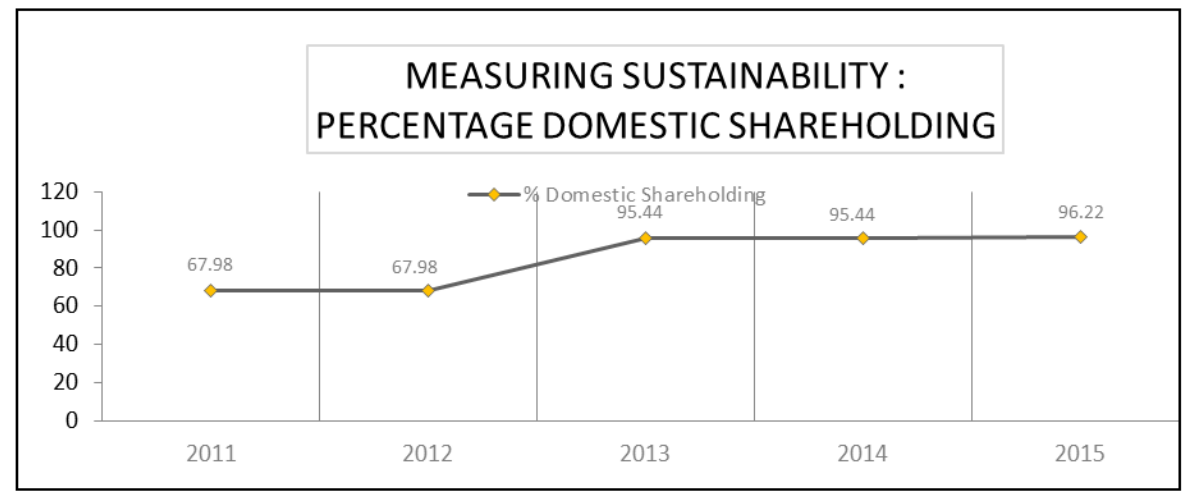

Figure 4. Measuring Sustainability through percentage of Domestic Shareholding

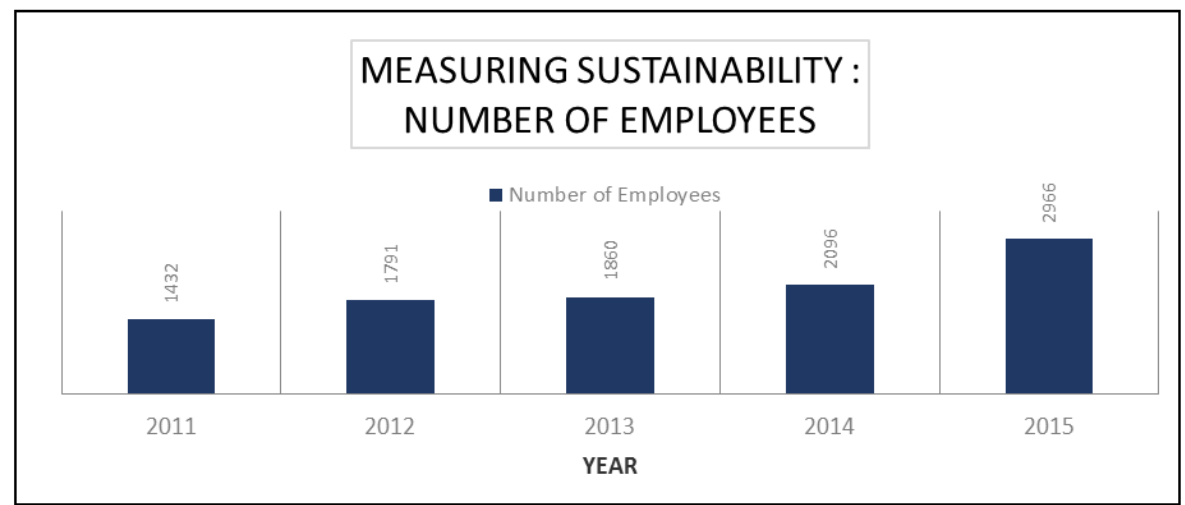

Figure 5. Measuring Sustainability through Number of Employees

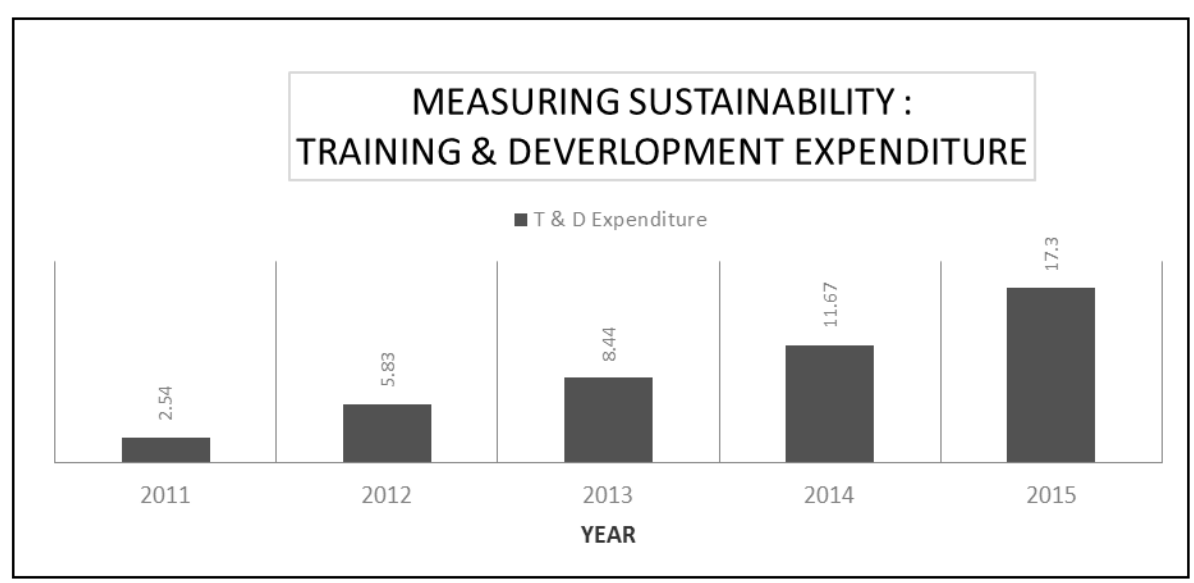

Figure 6. Measuring Sustainability through Training and Development expenditure

Table 4. Sustainability indicators (Scoring Values)

\begin{tabular}{|c|c|c|c|c|c|c|c|c|c|c|}
\hline \multirow{2}{*}{ Components } & \multicolumn{5}{|c|}{ Mean } & \multicolumn{5}{c|}{ Total } \\
\cline { 2 - 13 } & $\mathbf{2 0 1 5}$ & $\mathbf{2 0 1 4}$ & $\mathbf{2 0 1 3}$ & $\mathbf{2 0 1 2}$ & $\mathbf{2 0 1 1}$ & $\mathbf{2 0 1 5}$ & $\mathbf{2 0 1 4}$ & $\mathbf{2 0 1 3}$ & $\mathbf{2 0 1 2}$ & $\mathbf{2 0 1 1}$ \\
\hline ERP & 0.89 & 0.80 & 0.56 & 0.13 & 0.09 & 27 & 24 & 17 & 4 & 3 \\
\hline CER & 0.93 & 0.86 & 0.46 & 0.30 & 0.14 & 28 & 26 & 14 & 9 & 5 \\
\hline GB & 0.98 & 0.96 & 0.70 & 0.46 & 0.29 & 29 & 29 & 21 & 14 & 11 \\
\hline I\&S & 1.00 & 1.00 & 0.56 & 0.36 & 0.22 & 30 & 30 & 17 & 11 & 7 \\
\hline
\end{tabular}




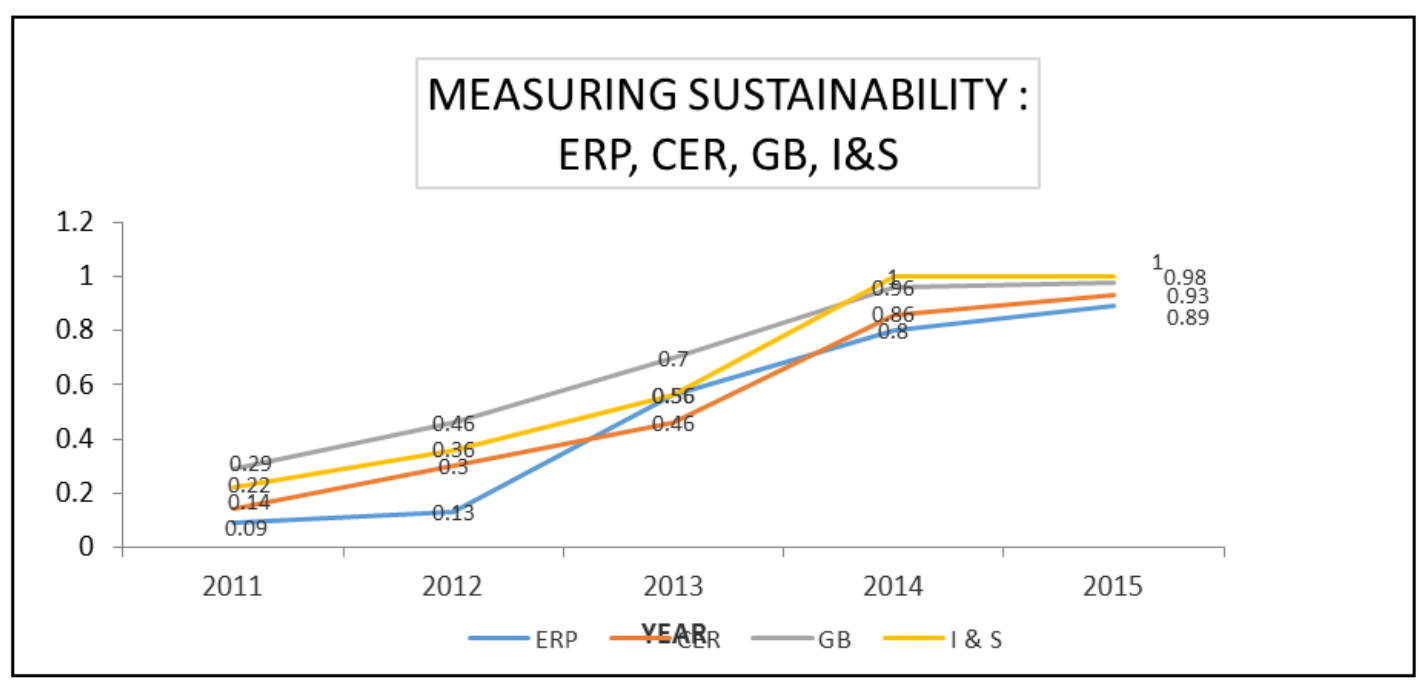

Figure 7. Measuring Sustainability through ERP, CER, GB and I\&S

Table 5. Corporate Governance (Scoring Value)

\begin{tabular}{|c|c|c|c|c|c|c|c|c|c|c|c|c|c|c|c|}
\hline & \multicolumn{5}{|c|}{ Mean } & \multicolumn{5}{|c|}{ Standard deviation } & \multicolumn{5}{|c|}{ Total } \\
\hline & 2015 & 2014 & 2013 & 2012 & 2011 & 2015 & 2014 & 2013 & 2012 & 2011 & 2015 & 2014 & 2013 & 2012 & 2011 \\
\hline IDB & 1 & 1 & 0.83 & 0.73 & 0.63 & 0 & 0 & -0.37 & -0.44 & -0.48 & 30 & 30 & 25 & 22 & 19 \\
\hline CC & 1 & 1 & 0.87 & 0.70 & 0.54 & 0 & 0 & -0.34 & -0.46 & -0.43 & 30 & 30 & 26 & 21 & 13 \\
\hline ACM & 1 & 1 & 0.90 & 0.70 & 0.63 & 0 & 0 & -0.30 & -0.46 & -0.48 & 30 & 30 & 27 & 21 & 19 \\
\hline BM & 1 & 1 & 0.83 & 0.73 & 0.54 & 0 & 0 & -0.37 & -0.44 & -0.43 & 30 & 30 & 25 & 22 & 13 \\
\hline GD & 1 & 1 & 0.70 & 0.63 & 0.40 & 0 & 0 & -0.46 & -0.48 & -0.53 & 30 & 30 & 21 & 19 & 8 \\
\hline BS & 0.67 & 0.67 & 0.63 & 0.50 & 0.23 & -0.47 & -0.47 & -0.48 & -0.50 & -0.61 & 20 & 20 & 19 & 15 & 5 \\
\hline CAS & 1 & 0.87 & 0.83 & 0.70 & 0.54 & 0 & -0.34 & -0.37 & -0.46 & -0.43 & 30 & 26 & 25 & 21 & 13 \\
\hline ID & 1 & 1 & 0.83 & 0.73 & 0.63 & 0 & 0 & -0.37 & -0.44 & -0.48 & 30 & 30 & 25 & 22 & 19 \\
\hline
\end{tabular}

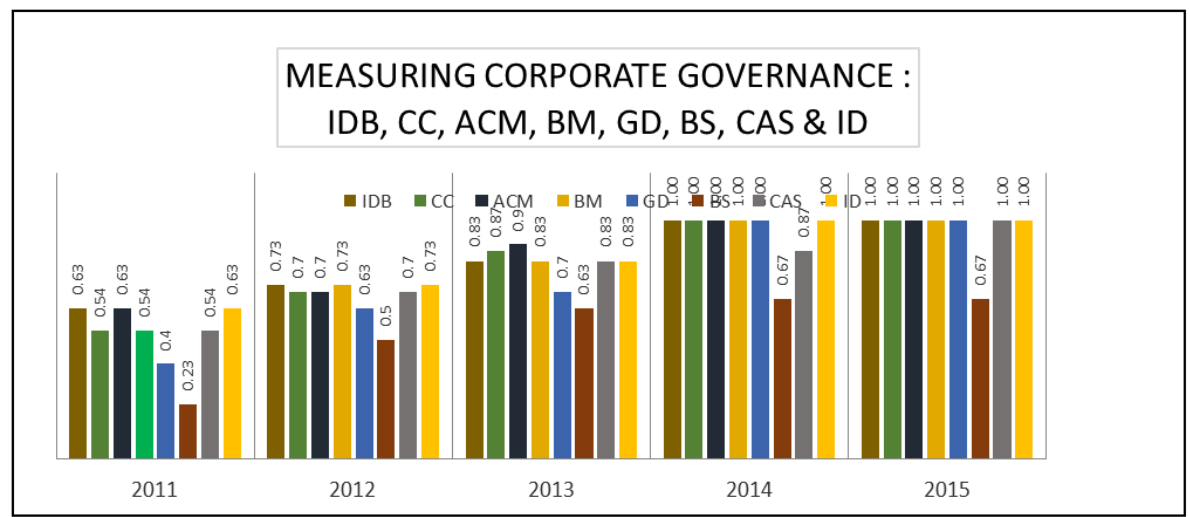

Figure 8. Measuring Corporate Governance 


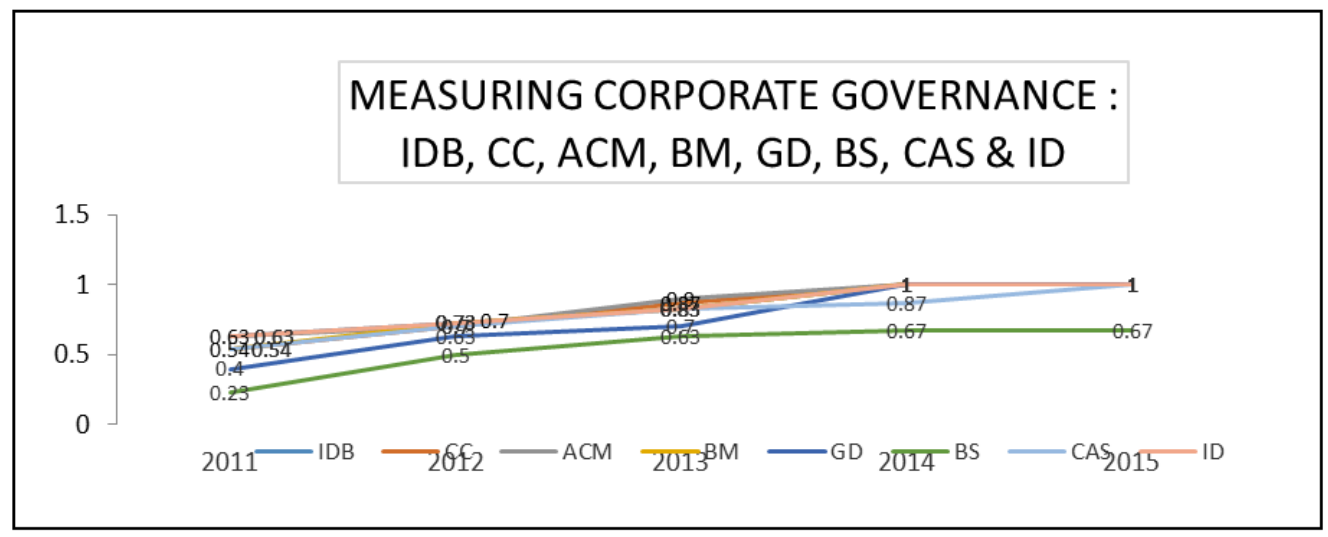

Figure 9. Measuring Corporate Governance

Table 6. Corporate Social Responsibility (In Millions)

\begin{tabular}{|l|l|l|l|l|l|l|l|l|l|l|}
\hline \multirow{2}{*}{ Component } & \multicolumn{5}{|c|}{ Mean } & \multicolumn{5}{c|}{ Total } \\
\cline { 2 - 11 } & $\mathbf{2 0 1 5}$ & $\mathbf{2 0 1 4}$ & $\mathbf{2 0 1 3}$ & $\mathbf{2 0 1 2}$ & $\mathbf{2 0 1 1}$ & $\mathbf{2 0 1 5}$ & $\mathbf{2 0 1 4}$ & $\mathbf{2 0 1 3}$ & $\mathbf{2 0 1 2}$ & $\mathbf{2 0 1 1}$ \\
\hline CSREX & 113.42 & 100.63 & 85.97 & 70.80 & 26.67 & 3402.50 & 3001.90 & 2407.31 & 1628.52 & 800.32 \\
\hline
\end{tabular}

Table 7. Trends of sectoral Patterns of CSR Expenditure reported by Banks

\begin{tabular}{|l|l|l|l|l|l|l|l|l|l|l|}
\hline Trends of sectoral Patterns of CSR Expenditure reported by Banks (Taka in Millions) \\
\hline \multirow{2}{*}{ Sectors } & $\mathbf{2 0 1 0}$ & $\mathbf{2 0 1 1}$ & $\mathbf{2 0 1 2}$ & $\mathbf{2 0 1 3}$ & \multicolumn{2}{l|}{$\mathbf{2 0 1 4}$} \\
\cline { 2 - 12 } & Amount & $\mathbf{\%}$ & Amount & $\mathbf{\%}$ & Amount & $\mathbf{\%}$ & Amount & \% & Amount & \% \\
\hline Education & 460.41 & 19.76 & 612.48 & 27.99 & 983.69 & 32.29 & 1295.18 & 28.97 & 1508.00 & 29.54 \\
\hline Health & 400.79 & 17.20 & 520.42 & 23.78 & 435.43 & 14.29 & 481.68 & 10.77 & 1383.70 & 27.10 \\
\hline Humanitarian \& Disaster Relief & 689.07 & 29.58 & 188.03 & 8.59 & 788.37 & 25.88 & 1385.83 & 30.99 & 949.47 & 18.60 \\
\hline Sports & 265.23 & 11.38 & 359.07 & 16.41 & 183.85 & 6.03 & 384.02 & 8.59 & 207.37 & 4.06 \\
\hline Art and Culture & 328.91 & 14.12 & 171.52 & 7.84 & 213.31 & 7.00 & 124.75 & 2.79 & 407.11 & 7.97 \\
\hline Environment & 59.78 & 2.57 & 138.07 & 6.31 & 140.23 & 4.60 & 106.59 & 2.38 & 164.55 & 3.22 \\
\hline Others & 125.58 & 5.39 & 198.73 & 9.08 & 301.81 & 9.91 & 693.41 & 15.51 & 485.24 & 9.50 \\
\hline Total & $\mathbf{2 3 2 9 . 7 7}$ & $\mathbf{1 0 0 . 0 0}$ & $\mathbf{2 1 8 8 . 3 2}$ & $\mathbf{1 0 0 . 0 0}$ & $\mathbf{3 0 4 6 . 6 9}$ & $\mathbf{1 0 0 . 0 0}$ & $\mathbf{4 4 7 1 . 4 6}$ & $\mathbf{1 0 0 . 0 0}$ & $\mathbf{5 1 0 5 . 4 4}$ & $\mathbf{1 0 0 . 0 0}$ \\
\hline
\end{tabular}

Source: Annual CSR Publications

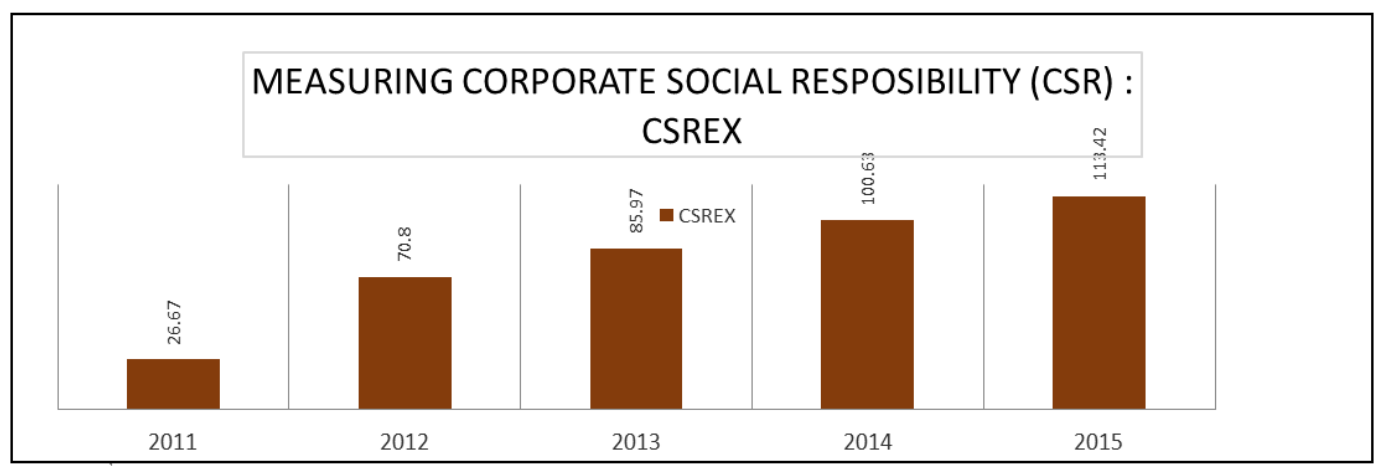

Figure 10. Measuring Corporate Social Responsibility 


\section{Ml Macrothink}

Business and Economic Research

ISSN 2162-4860

2019, Vol. 9, No. 4

Table 8. Intellectual Capital Disclosure (In Millions)

\begin{tabular}{|c|c|c|c|c|c|c|c|c|c|c|c|c|c|c|c|}
\hline \multirow[t]{2}{*}{ Component } & \multicolumn{5}{|l|}{ Mean } & \multicolumn{5}{|c|}{ Standard Deviation } & \multicolumn{5}{|l|}{ Total } \\
\hline & 2015 & 2014 & 2013 & 2012 & 2011 & 2015 & 2014 & 2013 & 2012 & 2011 & 2015 & 2014 & 2013 & 2012 & 2011 \\
\hline MVA & 985.3 & 1455.1 & 2062.8 & 3044.6 & 3304.7 & 3125.9 & 4045.1 & 3703.1 & 4478.6 & 4452.2 & 29559 & 46560.6 & 66012.1 & 97426.9 & 99141.2 \\
\hline
\end{tabular}

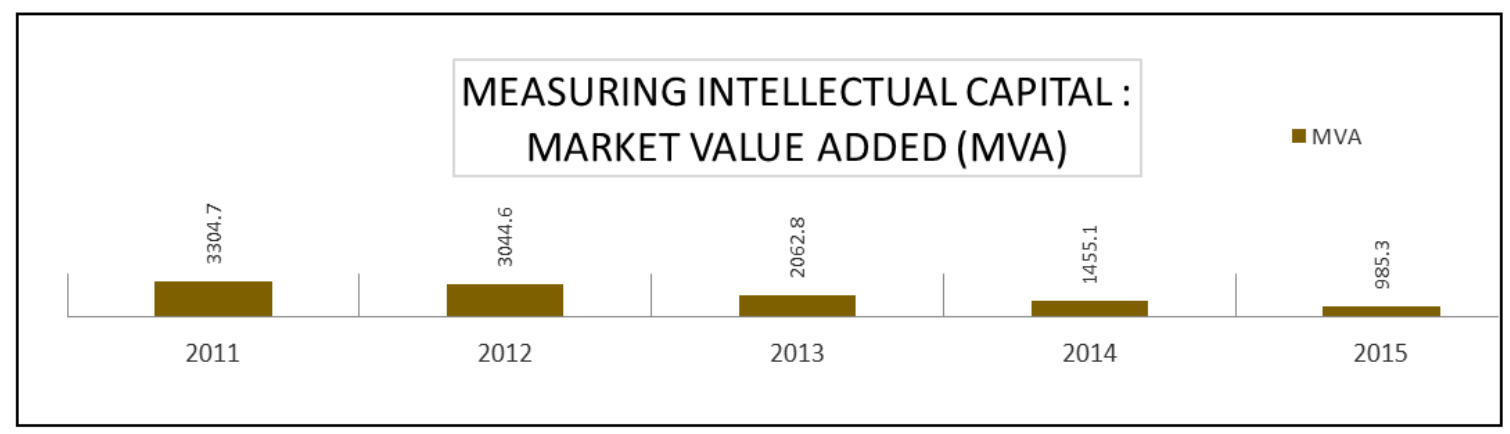

Figure 11. Measuring Intellectual Capital through MVA

Table 9. Correlation Matrix between All the Variables

\begin{tabular}{|c|c|c|c|c|c|c|c|c|c|c|c|c|c|c|c|c|c|c|c|c|c|c|}
\hline & $\begin{array}{l}\mathbf{P} \\
\mathbf{A} \\
\mathbf{T} \\
\end{array}$ & $\begin{array}{l}\mathbf{T} \\
\mathbf{A}\end{array}$ & $\begin{array}{l}\mathbf{R} \\
\mathbf{O} \\
\mathbf{A}\end{array}$ & $\begin{array}{l}\mathbf{R} \\
\mathbf{O} \\
\mathbf{E} \\
\end{array}$ & $\begin{array}{l}\mathbf{P} \\
\mathrm{D} \\
\mathrm{S} \\
\end{array}$ & $\begin{array}{l}\mathbf{N} \\
\mathbf{E}\end{array}$ & $\begin{array}{l}\text { T } \\
\& \\
\text { D } \\
\end{array}$ & $\begin{array}{l}\mathbf{I} \\
\mathbf{A}\end{array}$ & $\begin{array}{l}\mathbf{E} \\
\mathbf{R} \\
\mathbf{P} \\
\end{array}$ & $\begin{array}{l}\mathbf{C} \\
\mathbf{E} \\
\mathbf{R} \\
\end{array}$ & $\begin{array}{l}\text { G } \\
\text { B }\end{array}$ & $\begin{array}{l}\mathbf{I} \\
\& \\
\mathbf{S} \\
\end{array}$ & $\begin{array}{l}\text { I } \\
\text { D } \\
\text { B }\end{array}$ & $\begin{array}{l}\mathrm{C} \\
\mathrm{C}\end{array}$ & $\begin{array}{l}\mathbf{A} \\
\mathbf{C} \\
\mathbf{M} \\
\end{array}$ & $\begin{array}{l}\text { B } \\
\text { M }\end{array}$ & $\begin{array}{l}\text { G } \\
\text { D }\end{array}$ & $\begin{array}{l}\text { B } \\
\mathbf{S}\end{array}$ & $\begin{array}{l}\mathrm{C} \\
\mathrm{A} \\
\mathrm{S} \\
\end{array}$ & $\begin{array}{l}\text { I } \\
\text { D }\end{array}$ & $\begin{array}{l}\text { CSR } \\
\mathbf{E} \\
\mathrm{X} \\
\end{array}$ & $\begin{array}{l}\mathbf{M} \\
\mathbf{V} \\
\mathbf{A} \\
\end{array}$ \\
\hline PAT & 1.00 & 0.50 & 0.99 & 0.97 & 0.87 & 0.95 & 1.00 & 0.85 & 0.99 & 0.97 & 1.00 & 0.98 & 0.99 & 1.00 & 0.98 & 0.99 & 0.94 & 0.96 & 0.96 & 0.99 & 0.87 & -0.99 \\
\hline TA & 0.50 & 1.00 & 0.62 & 0.70 & 0.86 & 0.21 & 0.44 & 0.88 & 0.63 & 0.28 & 0.46 & 0.30 & 0.36 & 0.56 & 0.65 & 0.36 & 0.17 & 0.73 & 0.73 & 0.36 & 0.01 & -0.61 \\
\hline ROA & 0.99 & 0.62 & 1.00 & 0.99 & 0.93 & 0.90 & 0.98 & 0.91 & 1.00 & 0.93 & 0.98 & 0.94 & 0.96 & 1.00 & 1.00 & 0.96 & 0.88 & 0.99 & 0.99 & 0.96 & 0.79 & -1.00 \\
\hline ROE & 0.97 & 0.70 & 0.99 & 1.00 & 0.97 & 0.85 & 0.95 & 0.95 & 1.00 & 0.88 & 0.96 & 0.89 & 0.92 & 0.98 & 1.00 & 0.92 & 0.82 & 1.00 & 1.00 & 0.92 & 0.72 & -0.99 \\
\hline PDS & 0.87 & 0.86 & 0.93 & 0.97 & 1.00 & 0.68 & 0.83 & 1.00 & 0.93 & 0.73 & 0.85 & 0.74 & 0.78 & 0.90 & 0.94 & 0.78 & 0.65 & 0.97 & 0.97 & 0.78 & 0.51 & -0.93 \\
\hline NE & 0.95 & 0.21 & 0.90 & 0.85 & 0.68 & 1.00 & 0.97 & 0.64 & 0.89 & 1.00 & 0.96 & 1.00 & 0.99 & 0.93 & 0.88 & 0.99 & 1.00 & 0.82 & 0.82 & 0.99 & 0.98 & -0.90 \\
\hline T\&D & 1.00 & 0.44 & 0.98 & 0.95 & 0.83 & 0.97 & 1.00 & 0.81 & 0.98 & 0.99 & 1.00 & 0.99 & 1.00 & 0.99 & 0.97 & 1.00 & 0.96 & 0.94 & 0.94 & 1.00 & 0.90 & -0.98 \\
\hline IA & 0.85 & 0.88 & 0.91 & 0.95 & 1.00 & 0.64 & 0.81 & 1.00 & 0.92 & 0.70 & 0.82 & 0.71 & 0.76 & 0.88 & 0.93 & 0.76 & 0.61 & 0.96 & 0.96 & 0.76 & 0.47 & -0.91 \\
\hline ERP & 0.99 & 0.63 & 1.00 & 1.00 & 0.93 & 0.89 & 0.98 & 0.92 & 1.00 & 0.92 & 0.98 & 0.93 & 0.95 & 1.00 & 1.00 & 0.95 & 0.88 & 0.99 & 0.99 & 0.95 & 0.78 & -1.00 \\
\hline CER & 0.97 & 0.28 & 0.93 & 0.88 & 0.73 & 1.00 & 0.99 & 0.70 & 0.92 & 1.00 & 0.98 & 1.00 & 1.00 & 0.95 & 0.91 & 1.00 & 0.99 & 0.86 & 0.86 & 1.00 & 0.96 & -0.93 \\
\hline GB & 1.00 & 0.46 & 0.98 & 0.96 & 0.85 & 0.96 & 1.00 & 0.82 & 0.98 & 0.98 & 1.00 & 0.99 & 0.99 & 0.99 & 0.97 & 0.99 & 0.95 & 0.94 & 0.94 & 0.99 & 0.89 & -0.98 \\
\hline I\&S & 0.98 & 0.30 & 0.94 & 0.89 & 0.74 & 1.00 & 0.99 & 0.71 & 0.93 & 1.00 & 0.99 & 1.00 & 1.00 & 0.96 & 0.92 & 1.00 & 0.99 & 0.87 & 0.87 & 1.00 & 0.96 & -0.94 \\
\hline IDB & 0.99 & 0.36 & 0.96 & 0.92 & 0.78 & 0.99 & 1.00 & 0.76 & 0.95 & 1.00 & 0.99 & 1.00 & 1.00 & 0.97 & 0.94 & 1.00 & 0.98 & 0.90 & 0.90 & 1.00 & 0.94 & -0.96 \\
\hline $\mathrm{CC}$ & 1.00 & 0.56 & 1.00 & 0.98 & 0.90 & 0.93 & 0.99 & 0.88 & 1.00 & 0.95 & 0.99 & 0.96 & 0.97 & 1.00 & 0.99 & 0.97 & 0.91 & 0.98 & 0.98 & 0.97 & 0.83 & -1.00 \\
\hline ACM & 0.98 & 0.65 & 1.00 & 1.00 & 0.94 & 0.88 & 0.97 & 0.93 & 1.00 & 0.91 & 0.97 & 0.92 & 0.94 & 0.99 & 1.00 & 0.94 & 0.86 & 0.99 & 0.99 & 0.94 & 0.77 & -1.00 \\
\hline BM & 0.99 & 0.36 & 0.96 & 0.92 & 0.78 & 0.99 & 1.00 & 0.76 & 0.95 & 1.00 & 0.99 & 1.00 & 1.00 & 0.97 & 0.94 & 1.00 & 0.98 & 0.90 & 0.90 & 1.00 & 0.94 & -0.96 \\
\hline GD & 0.94 & 0.17 & 0.88 & 0.82 & 0.65 & 1.00 & 0.96 & 0.61 & 0.88 & 0.99 & 0.95 & 0.99 & 0.98 & 0.91 & 0.86 & 0.98 & 1.00 & 0.80 & 0.80 & 0.98 & 0.99 & -0.89 \\
\hline BS & 0.96 & 0.73 & 0.99 & 1.00 & 0.97 & 0.82 & 0.94 & 0.96 & 0.99 & 0.86 & 0.94 & 0.87 & 0.90 & 0.98 & 0.99 & 0.90 & 0.80 & 1.00 & 1.00 & 0.90 & 0.69 & -0.99 \\
\hline CAS & 0.96 & 0.73 & 0.99 & 1.00 & 0.97 & 0.82 & 0.94 & 0.96 & 0.99 & 0.86 & 0.94 & 0.87 & 0.90 & 0.98 & 0.99 & 0.90 & 0.80 & 1.00 & 1.00 & 0.90 & 0.69 & -0.99 \\
\hline ID & 0.99 & 0.36 & 0.96 & 0.92 & 0.78 & 0.99 & 1.00 & 0.76 & 0.95 & 1.00 & 0.99 & 1.00 & 1.00 & 0.97 & 0.94 & 1.00 & 0.98 & 0.90 & 0.90 & 1.00 & 0.94 & -0.96 \\
\hline CSREX & 0.87 & 0.01 & 0.79 & 0.72 & 0.51 & 0.98 & 0.90 & 0.47 & 0.78 & 0.96 & 0.89 & 0.96 & 0.94 & 0.83 & 0.77 & 0.94 & 0.99 & 0.69 & 0.69 & 0.94 & 1.00 & -0.80 \\
\hline MVA & -0.99 & -0.61 & -1.00 & -0.99 & -0.93 & -0.90 & -0.98 & -0.91 & -1.00 & -0.93 & -0.98 & -0.94 & -0.96 & -1.00 & -1.00 & -0.96 & -0.89 & -0.99 & -0.99 & -0.96 & -0.80 & 1.00 \\
\hline
\end{tabular}

\section{Findings}

From table 3, Sustainability has been calculated for private commercial banks for the five years (2011-2015). It has been identified that private commercial banks gradually increasing sustainability or tend to be more sustain in the market as per the analysis result. All the variables such as Profit after tax, Total asset, Infrastructural asset, ROA, ROE, Percentage domestic shareholding, Number of employees and Training \& Development expenses are 
gradually increasing year by year. The combine result shows a positive indication of sustainability among the commercial banking sector of Bangladesh.

The variable that has taken to conduct scoring has also given the similar result. Implementation of ERP, Certifications, adaptation of green banking policy and long-term incentives \& sanctions are rising upward among the focused timeframe. Alike table 3, table 4 also indicate the sustainable practice among Private commercial banks.

Corporate Governance determination has been fully based on scoring basis and the variables has been chosen from the statistics initiated by Bangladesh Bank. From table 5, CG practices have been increases among the private commercial banks. That also means private commercial banks are more focused on maintaining the $\mathrm{CG}$ practices. The table also shows among 8 variables, 7 of the components have been maintained by all the sample banks in 2015.

In terms of corporate social responsibility expenditure, table 7 shows the upward trends year by year. The expenditure has been increased 147 percent from 2012-13, 117 percent from 2013-14. The CSR result also consistent such as the above component.

Intellectual capital has been calculated thorough MVA (Market Value Added) which is considered the most effective measurement and used in other indexes. From table 8, an inverse relation has been identified with the time and MVA. The highest MVA has been determined in 2011 of all banks and the amount is BDT 99,141.2 million.

Correlation matrix (Table 9) shows except MVA, all the variables are positively related. That means CG and CSR are affecting the components of suitability positively. In the other hand, ICD and the component of sustainability are inversely related. This mismatch is the result of limited practice of ICD in the private commercial banking sector of Bangladesh.

Correlation matrix and path coefficient (table 8 and 9) of the hypothesis statement shows the companies with good board practices tend to have higher expenditure in corporate social responsibility. But due to limited disclosure of intellectual capital in private commercial banks, companies with high intellectual disclosure do not tend to have good corporate governance practices.

Table 10. Hypothesis Result

\begin{tabular}{|c|c|c|c|}
\hline Hypothesis No. & Hypothesis & $\begin{array}{c}\text { Suggested } \\
\text { Effect }\end{array}$ & Path Coefficient \\
\hline H1 & $\begin{array}{c}\text { All else being equal, banks with good board practices tend to } \\
\text { have higher expenditure in Corporate Social Responsibility } \\
\text { (CSR). }\end{array}$ & + & 0.8487 \\
H2 & $\begin{array}{c}\text { All else being equal, banks with high Intellectual Capital } \\
\text { Disclosures tend to have good Corporate Governance (CG) } \\
\text { Practices. }\end{array}$ & + & -0.968 \\
\hline
\end{tabular}

\section{Recommendations}

Board structure should be efficient that could add more value to both corporation and 
shareholders. More than efficient could impact on decision making and overall performance of directors. Less than efficient could directly impact on direction and control over management and stockholders.

Standard authority and accountability should ensure to the Independent directors. Number of Independent directors should match the efficient level. Less than efficient can leads a corporation towards corruption and unethical practices.

Banks should maintain Government and regulators requirements. In addition, those rules are updating overtime. So Financial institutions also needed to update with new regulations.

Banks should identify and explore the possible improvements and provides priority-based suggestions to improve Corporate Governance practices.

Government needs to establish regulatory bodies that will monitor the social responsibility of corporate organizations, in order to oversee the compliance of CSR policies and prosecute organizations that are socially irresponsible.

It is recommended to encourage the financial institutions more in CSR by announcing different benefits like awards, removing the ceiling in CSR, inclusion in company law, progressive tax exemption rate etc.

Initiatives from Bangladesh Bank are needed to ensure proper disclosure of Intellectual capital.

A major recommendation for private commercial banks is to develop strategic and tactical initiatives that provide for voluntary disclosure of intellectual capital. These initiatives may initially be used for internal management purposes only. However, an external stakeholder focus report will more than likely be the goal.

Firms that provide enhanced disclosures for both financial and intellectual capital disclosures do benefit more in terms of a lower cost of equity capital, suggesting that intellectual capital and financial disclosures are complementary.

Central banks or regulatory and supervisory authorities should develop appropriate legal framework for controlling, guiding and supervising the banking system.

\section{Conclusion}

CG practices have been increases among the private commercial banks. That also means private commercial banks are more focused on maintaining the CG practices. The CSR outcome also consistent such as the above component but an inverse relation has been identified with the time and ICD. ICD is not properly maintained in our private commercial banking sector. Even ICD has not properly disclosed in the annual reports or any other sources. There is no evidence that ICD has garnered any traction for private commercial banks in Bangladesh. The results also support the ICD trends in prospects of Bangladesh. Confidentiality of data had been found to be a setback to this study. There are many other factors that could be used in assessing the sustainability but is restricted from being utilized in the study due to its confidentiality issue, where it was an obstacle to obtain certain types of 
material. Banks have been playing a vital role in socio-economic, industrial, and agricultural development as well as in the overall economic development of the country through deposit mobilization. So, sustainability issue of banks is an important dimension which needs to be considered carefully. Overall this report has given a real image of this scenario. It tried to find the problems, compare it with other sectors and showed the reason for this error. Moreover, it tries to find the possible solution for overcoming all adverse situations. we hope that this study will open ways for further study on the topic.

\section{References}

Bouma, J. J., Jeucken, M., \& Klinkers, L. (2001). Sustainable Banking. The Greening of Finance (Sheffield: Greenleaf Publishing).

Brundtland Commission. (1987). Report of the World Commission on Environment and Development: Our common future, transmitted to the United Nations General Assembly as an Annex to document A/42/427. Development and International Co-operation: Environment.

Claessens, S., \& Fan, J. P. (2002). Corporate governance in Asia: A survey. International Review of finance, 3(2), 71-103. https://doi.org/10.1111/1468-2443.00034

Cleary, P., Kennedy, T., O'Donnell, D., O'Regan, P., \& Bontis, N. (2007). Positioning management accounting on the intellectual capital agenda. International Journal of Accounting, Auditing and Performance Evaluation, 4(4-5), 336-359.

https://doi.org/10.1504/IJAAPE.2007.017083

Clough, G. W., Chameau, J. L., \& Carmichael, C. (2006). Sustainability and the University. Presidency, 9(1), 30.

Cogan, D. G. (2008). Corporate governance and climate change: The banking sector.

Gwin, C., \& Libman, M. L. (2007). Banking on sustainability: financing environmental and social opportunities in emerging markets.

Low, J., \& Kalafut, P. C. (2002). Invisible advantage. How Intangibles are Driving Business Performance, Perseus, Cambridge.

Makarov, P. (2010). Intellectual capital as an indicator of a sustainable development. Journal of Sustainable Development, 3(3), 85. https://doi.org/10.5539/jsd.v3n3p85

O'Donnell, D., Henriksen, L. B., Voelpel, S. C., \& Abeysekera, I. (2006). The project of intellectual capital disclosure: researching the research. Journal of intellectual capital.

Pisano, U., Martinuzzi, A., \& Bruckner, B. (2012). The Financial Sector and Sustainable Development: Logics. Principles and Actors.

Rowe, D. (2002). Environmental literacy and sustainability as core requirements: success stories and models. Teaching sustainability at universities, 79-103.

Shleifer, A., \& Vishny, R. W. (1997). A survey of corporate governance. The journal of finance, 52(2), 737-783. https://doi.org/10.1111/j.1540-6261.1997.tb04820.x 
Sujan, A., \& Abeysekera, I. (2007). Intellectual capital reporting practices of the top Australian firms. Australian Accounting Review, 17(42), 71-83.

https://doi.org/10.1111/j.1835-2561.2007.tb00445.x

\section{Copyright Disclaimer}

Copyright for this article is retained by the author(s), with first publication rights granted to the journal.

This is an open-access article distributed under the terms and conditions of the Creative Commons Attribution license (http://creativecommons.org/licenses/by/3.0/). 